\title{
Problem based learning: Students' mental models on water conductivity concept
}

\author{
John Rafafy Batlolona ${ }^{1}$, Haryo Franky Souisa ${ }^{2}$ \\ ${ }^{1}$ Teacher Professional Education Study Program, Pattimura University, Indonesia \\ ${ }^{2}$ Primary School Teacher Education Study Program, Universitas Nani Bili Nusantara, Indonesia
}

\begin{abstract}
Article Info
Article history:

Received Jan 10, 2020

Revised Mar 30, 2020

Accepted Apr 29, 2020

Keywords:

Conductivity

Mental model

Misconceptions

Physics

Problem based learning

ABSTRACT

This paper tells about the mental model of prospective scholars on the topic of temperature and heat. The purpose of this research is to improve students' mental model by using problem based learning (PBL) model. The number of samples in the study amounted to 72 students with two different classes. The results of the study showed that, (1) the improvement of mental model that studied with PBL was higher than that studied with conventional learning. (2) high-skilled student mental models that are learning with PBL are higher than those studied by conventional learning. (3) low-skilled student mental models that study with PBL are higher than students learning with conventional learning. The conclusion of this study is the improvement of students' mental models using PBL models on the topic of conductivity in water. Thus the PBL model can be recommended in improving students' mental models on temperature and heat topics. The implication in this research is to improve the students' mental model as the agent of science education change.
\end{abstract}

This is an open access article under the CC BY-SA license.

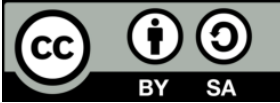

\section{Corresponding Author:}

John Rafafy Batlolona,

Teacher Professional Education Study Program,

Pattimura University,

Jln. Dr. Tamaela, Campus B FKIP-Pattimura University, Indonesia.

Email: johanbatlolona@gmail.com

\section{INTRODUCTION}

At present, many breakthroughs have been made regarding Nano science and technology. Physics and chemistry students are familiar with the concept of Nano science but the students of Teacher Education Elementary Education Program still have very limited knowledge because they are trained to be a classroom teacher. Therefore, it is time to learn and be taught to students on the atomic scale. This is a major step forward in the goal of Nano science education [1].

The effort to teach the concept of atoms is to increase the understanding of students' concepts with a mental model approach that is considered a learning product. It is reported that because mental models also play an important role in the learning process because learning can generally be seen as mental modeling [2]. Thus, mental models are considered important in science learning. According to experts, mental models provide valuable information about the concept of nanoscience of a conceptual framework, or underlying knowledge structure [3]. Therefore, capturing student mental models is one way to understand the content and structure of student knowledge about scientific concepts, and reflect student beliefs and interpretations of the system [4]. Now, there is a lot of research on mental models for various topics. Some examples include the mental model of natural phenomena [5], chemical bonds [6, 7], Materials [8], chemicals [9], atoms and molecules [10], acids and bases [11, 12], organic chemistry [13], thermal conduction [14], 
electricity [15, 16], earth and cosmology [17, 18], environment [19-21], ecology [22], Style and motion [23], circular motion [24], magnetism [25], modern physics [26], convection in water [27], Friction force [28], thermal conductivity in solids [29], Light, Energy and Angular Momentum [30].

Using models in science education has long been done. As explained earlier, the model plays a key role in science education with regard to internal representation [31], and is useful in helping to describe and understand a structure or property. The effect of heat conductivity on water has been debated by physicists and chemists on a continuous basis over the past few years [32]. The concept of temperature and heat is one of the topics studied by students in physics learning. So far, studies on how to study the state of water by connecting three levels of representation: macroscopic, sub-microscopic and symbolic levels have been taught in chemistry and physics learning by connecting three levels of representation reflecting the students' mental models are still limited. Although there are still on chemical topics, the physical conductivity of water is still limited [33]. Previous research still discusses the thermal conductivity of solids [34], convection in water [34], but the conductivity of water to describe physical conditions is still rarely studied. Therefore, one learning model that can facilitate the improvement of the student's mental model is problem based learning (PBL) [35]. In addition, PBL also trains students to communicate experiment, collaborate in teams, build ideas and develop independent learning skills [36].

PBL is a student-centered pedagogy, where students learn through problem solving experiences [37]. Learning begins with problems to be solved, posed in such a way that students need to gain new knowledge before they can solve the problem. The goals of PBL are to develop knowledge of creativity, problem-solving skills, self-study, collaboration skills and intrinsic motivation [38]. In this section, the research focuses on conductivity on water. Thus the purpose of this study is to improve students' mental models using the PBL model.

\section{RESEARCH METHOD}

\subsection{Research design}

This study was quasi experiment; employed pretest-posttest control gorup design. This study has two variables, namely the independent variable and the dependent variable. The independent variables in this research are PBL model in the experimental class and conventional learning in the control class, the dependent variable of the mental model.

\subsection{Research population and sample}

The population of this research is the 2 nd semester students who take the basic science and basic science basic course in elementary school teacher education program (PGSD), Pattimura University. The sampling technique used in this study is Cluster Random Sampling by randomly selecting. Basic science concept class is as experimental class and natural science class as control class. The number of samples is 72 with the experiment class category of 36 students and the control class of 36 students. All classes are taught temperature and heat topics that are more focused on conductivity in water.

\subsection{Research instruments}

Grain of mental model is used as a mental model of the students after being treated with a problem based learning (PBL) model. The item of mental model is a diagnostic test with 1 discourse and has 3 questions from the macroscopic level to the microscopic. As for the type of mental model adopts a rating column from levels 1 to 5, as shown in Table 1 [9].

Table 1. Indicators of mental models

\begin{tabular}{|c|c|}
\hline Mental Model Type & Criteria \\
\hline $\begin{array}{c}1 \\
\text { (Early Mental Model) }\end{array}$ & $\begin{array}{l}\text { Students Are Not Able To Answer With The Concept That Is In It Or Can Not Describe It And } \\
\text { Scientifically Unacceptable For Not Having Any Concept. }\end{array}$ \\
\hline $\begin{array}{c}2 \\
\text { (Intermediate Mental model 1) }\end{array}$ & $\begin{array}{l}\text { Students Already Begin to Be Able to Answer Correctly With The Concept That Is In Him } \\
\text { With The Model That is Started to be Formed And Its Explanation Becomes Scientific Nearer } \\
\text { With Truth. }\end{array}$ \\
\hline $\begin{array}{c}3 \\
\text { (Intermediate Mental model 2) }\end{array}$ & $\begin{array}{l}\text { Students Already Begin To Be Able to Answer Correctly With The Concept That Is In Him } \\
\text { With The Model That is Started to be Formed That The Explanation Is Partly True And Being } \\
\text { Scientific Nearer With The Truth. }\end{array}$ \\
\hline $\begin{array}{c}4 \\
\text { (Intermediate Mental model 3) }\end{array}$ & $\begin{array}{l}\text { Students Able to Answer Rightly and Provide True Explanations, Besides Being Able to } \\
\text { Provide Proper Answers Scientifically Can Be Accepted Scientifically Nearer With Truth. }\end{array}$ \\
\hline $\begin{array}{l}5 \\
\text { Target Mental Model }\end{array}$ & $\begin{array}{c}\text { Students Are Able To Answer Correctly And Provide Correct Explanation, Besides Being Able } \\
\text { To Provide Correct Conceptual Scientific Answers, Can Be Accepted Scientifically And } \\
\text { Explain The Structure Correctly. }\end{array}$ \\
\hline
\end{tabular}




\subsection{Data collection technique}

Data collection on the research was done gradually to be able to obtain the necessary data in a study. There are three stages of data collection in this study. The stages of data collection are pretest in the experimental class and control class with validated instrument by the validator, then carrying out the learning process using the PBL model and using the mental model instrument in the experimental class and the conventional learning process in the control class. The last stage performs posttest on the experimental class and control class.

\subsection{Data analysis}

Data analysis is an activity after data from all respondents or other data sources is collected. The data obtained from this study are quantitative data obtained from the results of mental model tests. To see the improvement of students' mental models using the gain score while the statistical tests for normality and homogeneity tests and further testing two-way ANOVA Advanced Tests are assisted by SPSS version 20 for Windows.

\section{RESULTS AND DISCUSSION}

Pretest data was obtained from two classes, namely the experimental class and the control class. A summary of the results of the pretest mastery of concepts can be seen in Table 2. Based on Table 2, it can be seen that the average pretest value of the experimental class mental model is 33 , while for the control class is 31.3. The difference between the average pretest value of the mental model between the experimental class and the control class is 1.7. The average pretest value of the experimental class mental model is higher than the control class. The mental model posttest data was obtained from the experimental class learning to use PBL models and control classes that learned to use conventional models. Summary of posttest result of mental model can be seen in Table 3 .

Table 2. Summary of pretest mental model results

\begin{tabular}{ccc}
\hline Variable & Experiment Class & Control Class \\
\hline Average & 33 & 31.3 \\
The highest Score & 66.7 & 60 \\
The Lowest Score & 13.3 & 13.3 \\
Number of Samples & 36 & 36 \\
\hline
\end{tabular}

Table 3. Summary of posttest result of mental model

\begin{tabular}{ccc}
\hline Variable & Experiment Class & Control Class \\
\hline Average & 73.5 & 52.4 \\
The highest Score & 93.3 & 86.7 \\
The Lowest Score & 53.3 & 26.7 \\
Number of Samples & 36 & 36 \\
\hline
\end{tabular}

Table 3 shows that the mean value of posttest mental model of experimental class is 73.5 , while for the control class is 52.4. Difference in mean posttest of mental model between experiment class and control class is 21.1. The mean posttest grade of the experimental model is higher than the control class. Gain score is used to determine the improvement of mental models of students between before and after being treated with the gain formula $=$ posttest - pretest. The mental model's gain score data can be seen in Table 4.

Based on Table 4, it can be seen that the average score gain score of the experimental class mental model is 41.7, while for the control class is 22.2. Difference between the mean score of concept comprehension score between the experimental class and the control class is 19.5. The average score gain score of the experimental model is higher than the control class. After grouping based on initial ability, we obtained the breakdown of high and low initial ability students in the mental model gain score presented in Table 5.

Table 4. Gain score mental model

\begin{tabular}{ccc}
\hline Variable & Experiment Class & Control Class \\
\hline Average & 41.7 & 22.2 \\
The highest Score & 66.7 & 46.7 \\
The Lowest Score & 13.3 & 6.6 \\
Number of Samples & 36 & 36 \\
\hline
\end{tabular}


Table 5. N-gain score mental models based on initial ability

\begin{tabular}{ccc}
\hline Variable & Experiment Class & Control Class \\
\hline Early High Ability & 44.4 & 27.8 \\
Initial Low Capability & 38.9 & 16.7 \\
\hline
\end{tabular}

Table 5 reveals that the average gain score of mental models in students with high initial ability in experimental class 44.4 and control class 27.8. Difference in the average mental gain score for students with high initial ability is 16.6. While the average gain score of the mental model on the low-ability students in the experimental class was 38.9 and the control class 16.7 with a difference of 22.2. Details of gain scores on mastery of high skilled student concept are presented in Table 6.

Table 6. Gain score mental models of high early capability

\begin{tabular}{ccc}
\hline Variable & Experiment Class & Control Class \\
\hline Average & 44.4 & 27.8 \\
The highest Score & 66.7 & 46.7 \\
The Lowest Score & 13.3 & 6.7 \\
Number of Samples & 12 & 12 \\
\hline
\end{tabular}

Table 6 shows that the mental model gains average score for students with high initial ability in the experimental class 44.4 and the control class 27.8. The difference in the average gain score of the mental model on the student with high initial ability is 16.6. The mean value of the mental model gain score in the high-ability students in the experimental class is higher than the control class. The details of the gain score of mental models of students with low initial abilities are presented in Table 7.

Table 7. Gain score mental models low ear capability

\begin{tabular}{ccc}
\hline Variable & Experiment Class & Control Class \\
\hline Average & 38.9 & 16.7 \\
The highest Score & 60.0 & 33.4 \\
The Lowest Score & 13.3 & 6.6 \\
Number of Samples & 12 & 12 \\
\hline
\end{tabular}

Table 7 explains that the average gain score of mental models on high-ability students is high in the experimental class 38.9 and the control class 16.7. The difference in the average gain score of the mental model on the low-skilled student is 22.2. The mean value of the mental model gain score in the low-ability students in the experimental class is higher than the control class. Description of test result of normality data mastery experiment mental model and control class with $5 \%$ significance value is presented in Table 8 . Based on Table 8 it is known that the mental model data of the experimental class and the control class has $\mathrm{L}_{\text {hit }}<\mathrm{L}_{\text {tab }}$ so that both data are normally distributed. The results of the mental model homogeneity test of the experimental class and control class for the 5\% significance value are presented in Table 9.

Table 8. Summary of mental model data normality test results

\begin{tabular}{ccccc}
\hline Data Type & Class & $\mathrm{L}_{\text {count }}$ & $\mathrm{L}_{\text {table }}$ & Note \\
\hline \multirow{2}{*}{ Gain Score } & Experiment & 0.128714 & 0.147667 & Normal \\
& Control & 0.121837 & 0.147667 & Normal \\
\hline
\end{tabular}

Table 9. Summary of homogeneity test results of mental models

\begin{tabular}{cccc}
\hline Data Type & $\mathrm{F}_{\text {count }}$ & $\mathrm{F}_{\text {table }}$ & Note \\
\hline Gain Score & 1.77458 & 3.12767 & Homogen \\
\hline
\end{tabular}

Table 9 shows the homogeneity test results; it can be seen that $F_{\text {count }}<\mathrm{F}_{\text {table }}$ which means the mental model between the experimental and control classes has a homogeneous variance. Based on hypothesis prerequisite test result that is normality test and homogeneity test, it is obtained that mental model data is normal and homogenous distributed, so to test hypothesis can be used parametric test that is test of Two-way ANOVA. Summary of Two-way ANOVA calculation result of experimental class data model and control class can be seen in Table 10.

Int. J. Eval. \& Res. Educ. Vol. 9, No. 2, June 2020: 269 - 277 
Table 10. Summary of two-way ANOVA data on mental models

\begin{tabular}{ccccccc}
\hline Source of Variation & $\mathrm{SS}$ & $\mathrm{df}$ & $\mathrm{MS}$ & $\mathrm{F}_{\text {count }}$ & $\mathrm{P}$-value & $\mathrm{F}_{\text {table }}$ \\
\hline Between Early Abilities (B) & 836.67 & 1 & 836.67 & 4.29 & 0.04 & 4.06 \\
Between Learning (A) & 4533.15 & 1 & 4533.15 & 23.26 & $1.72 \mathrm{E}-05$ & 4.06 \\
Interaction & 92.96 & 1 & 92.96 & 0.48 & 0.49 & 4.06 \\
In Group (D) & 8573.29 & 44 & 194.85 & & & \\
Total & 14036.08 & 47 & & & & \\
\hline
\end{tabular}

Based on Table 10 calculation between learning $(\mathrm{A})$ is known that $\mathrm{F}_{\mathrm{A} \text {-count }}>\mathrm{F}_{\text {table }}$ is $23.26>4.06$, so $\mathrm{H}_{\mathrm{o}}$ is rejected and $\mathrm{H}_{\mathrm{a}}$ is accepted. So it can be concluded that the improvement of mental models of students who study with PBL models is higher than students who learn with conventional learning. Based on Table 11 calculation between initial ability (B) is known that FB-arithmetic > $F_{\text {table }}$ is 4.29397> 4.06171, then $\mathrm{Ho}$ is rejected and $\mathrm{Ha}$ accepted. So it can be concluded that the improvement of mental models of students with high-ability early high-learning learning with PBL model is higher than students who learn with conventional learning. Based on the Table 11 the interaction between the initial ability (A) with the intermediate ability (B) is known that $\mathrm{F}_{\text {count }}<\mathrm{F}_{\text {table }}$ is $0.477108<4.06171$, then $\mathrm{H}_{\mathrm{o}}$ is rejected and $\mathrm{H}_{\mathrm{a}}$ accepted. So it can be concluded there is no interaction between the PBL model and the high-low initial ability to the improvement of the mental model. Furthermore, further tests were conducted using the Tukey test which results are presented in Table 11.

Table 11. Tukey test results for mental model

\begin{tabular}{ccc}
\hline & $\mathbf{Q}_{\text {1A-3A }}$ & $\mathbf{Q}_{\text {1B-3B }}$ \\
\hline $\mathbf{Q}_{\text {count }}$ & 8.26 & 11.03 \\
$\mathbf{Q}_{\text {table }}$ & 3.43 & 3.43 \\
\hline
\end{tabular}

From the advanced test analysis, the Tukey test presented in Table 11 obtained the results of $\mathrm{Q}_{1 \mathrm{~A}-3 \mathrm{~A}}>\mathrm{Q}_{\text {table }}$, then $\mathrm{H}_{\mathrm{o}}$ was rejected and $\mathrm{H}_{\mathrm{a}}$ was accepted. So it can be concluded that the increased mastery of the concept of a high initial ability to learn with PBL is higher than students who learn with conventional learning. In addition, from the advanced test analysis, the Tukey test presented in Table 11 obtained the results of $\mathrm{Q}_{1 \mathrm{~B}-3 \mathrm{~B}}>\mathrm{Q}_{\text {table }}$, so $\mathrm{H}_{\mathrm{o}}$ was rejected and $\mathrm{H}_{\mathrm{a}}$ was accepted. So it can be concluded that the increase in mastery of the concept of students with low initial abilities who learn with PBL is higher than students who learn with conventional learning.

The results of real data in the experiments prove that when the temperature increased then the particles will move faster and the volume of water also increases and vice versa when the temperature is lowered the particle movement is slower so that the volume of water also decreases. This can be shown in Figure 1 (a) and Figure 1 (b). Furthermore, proof of mental model of student through virtual activity shown in Figure 2 (a) and Figure 2 (b). The results of conversations with students in the experimental and control class to prove the mental model of the students can be shown in Table 12.

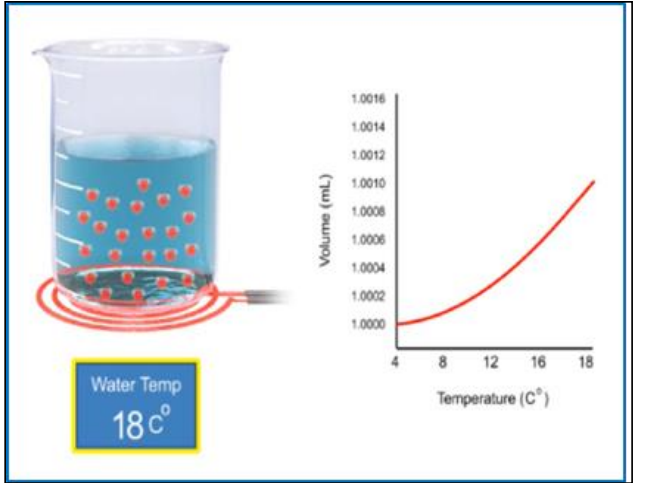

(a)

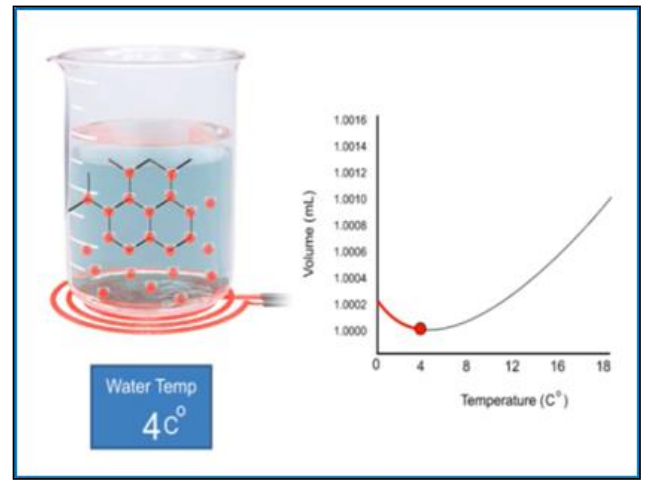

(b)

Figure 1 (a). The state of the particle when the temperature is increased by $18^{0} \mathrm{C}$, (b). The state of the particle when the temperature is lowered $4^{0} \mathrm{C}$ 


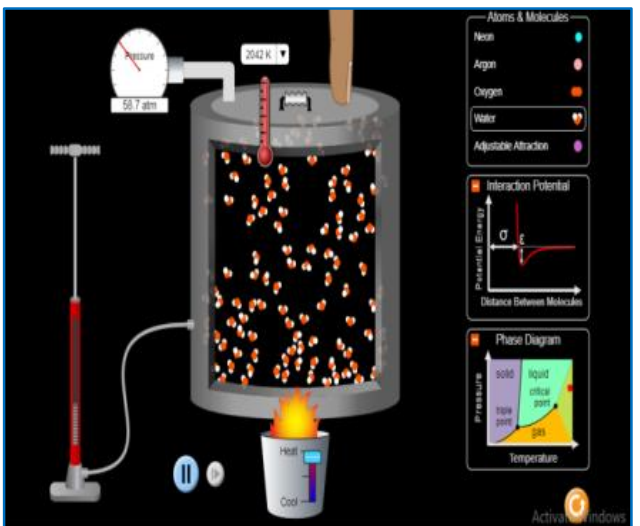

(a)

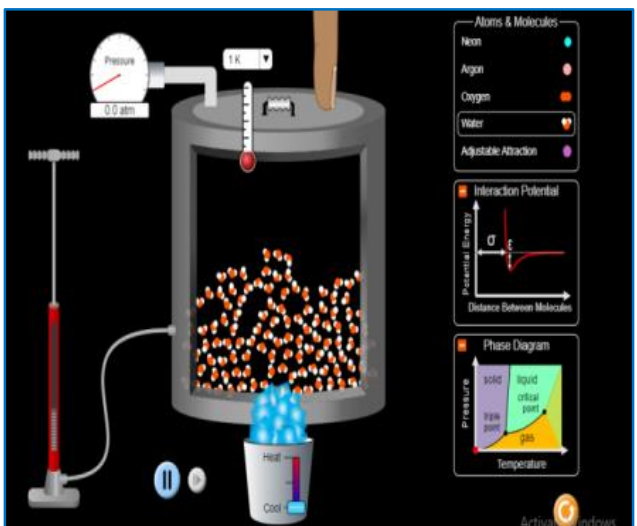

(b)

Figure 2 (a). The state of the particle when the temperature is increased by $2042 \mathrm{~K}$,

(b). Particle state when temperature decreases $1 \mathrm{~K}$

Table 12. Result of conversations with students in the experimental and control class

\begin{tabular}{|c|c|c|c|c|}
\hline Students & Questions & Answers & Class & $\begin{array}{l}\text { The type of mental } \\
\text { model }\end{array}$ \\
\hline $\mathrm{S}_{20}$ & $\begin{array}{l}\text { What is the state of the } \\
\text { water particle when } \\
\text { the temperature is } \\
\text { increased?. }\end{array}$ & $\begin{array}{c}\text { The energies of the } \\
\text { constituent particles get } \\
\text { bigger and the particles } \\
\text { move faster }\end{array}$ & Experiment & Intermediate 3 \\
\hline \multirow[t]{2}{*}{$\mathrm{S}_{30}$} & \multirow{2}{*}{$\begin{array}{l}\text { Describe the state of } \\
\text { water particles when } \\
\text { in the morning and } \\
\text { during the day. }\end{array}$} & 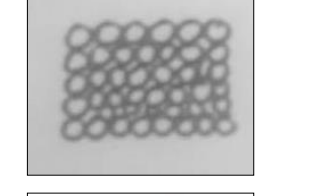 & $\begin{array}{c}\text { The temperature } \\
\text { is lowered }\end{array}$ & \multirow[t]{2}{*}{ Target Mental Model } \\
\hline & & $\begin{array}{ccc}0 & 0 & 0 \\
0 & 0 & 0 \\
0 & 0 & 0 \\
0 & 0 & 0\end{array}$ & $\begin{array}{c}\text { The } \\
\text { temperature is } \\
\text { lowered }\end{array}$ & \\
\hline $\mathrm{S}_{2}$ & $\begin{array}{l}\text { What is the state of a } \\
\text { particle when the } \\
\text { water temperature is at } \\
0^{\circ} \mathrm{C} \text { ? }\end{array}$ & $\begin{array}{c}\text { Water particles move faster } \\
\text { just like when water is } \\
\text { heated }\end{array}$ & Control & Early Mental Model \\
\hline $\mathrm{S}_{5}$ & $\begin{array}{l}\text { When water becomes } \\
\text { ice }\left(0^{0} \mathrm{c} \text {, energy in }\right. \\
\text { water molecules still } \\
\text { exists?. }\end{array}$ & $\begin{array}{l}\text { The molecules in water } \\
\text { still have energy, and the } \\
\text { atomic motion is much } \\
\text { slower. }\end{array}$ & & Intermediate 3 \\
\hline
\end{tabular}

The mental model of the experimental class students who were taught with the PBL model was higher than the control class that was taught with conventional learning. Based on the hypothesis test using Two-way ANOVA, it has been concluded that the improvement of mental models of students who study with PBL models is higher than those who learn with conventional learning. In PBL students are directly involved in learning activities so as to provide more opportunities to accommodate and understand information [39, 40]. Involvement in the learning process allows students to be able to use their mental processes to discover a concept or theory being studied [41]. The concept of chemical reactions between particles can be illustrated in Ping-Pong balls as in Figure 3. 


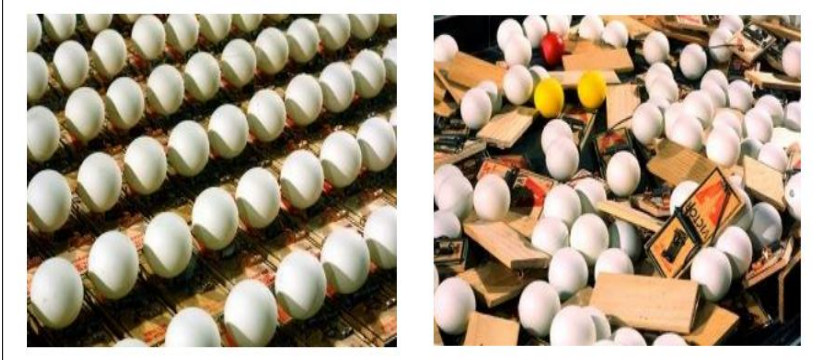

Figure 3. Ping-pong ball as an analogy model for chemical reactions between particles

At the beginning of the meeting students still have difficulty in formulating problems and making hypotheses. The next meeting, students begin to understand that to formulate the problem and make the hypothesis comes from the observation activities at the beginning of learning, the purpose of the experiment and the study of the literature. After students can formulate a hypothesis then students conduct an experiment. Students experiment actively to test the correctness of the hypothesis that has been made by students. By experimenting with learning becomes more interesting, students have full attention to the material they are learning and the students are more active. In addition, students are also trained to analyze the empirical data, so as to form the mastery of their concepts. PBLs have an advantage in engaging students in small groups with real-world problems in defining the knowledge and investigations needed to solve problems. PBL also facilitates students in solving problems and choosing new ways so as to solve existing problems [42].

Highly skilled group of students who are taught by PBL have a higher mental model than students learning with conventional learning as well as low-skilled student groups. This is because the experimental activities undertaken during the learning are done in groups. Use of group learning can improve student academic achievement and help achieve a better understanding of the concepts of physics [43]. Discussions were conducted by students during the experiment to obtain data, process data in hypothesis testing and draw conclusions. During the discussion there is a peer tutor in his group so that all members play an active role during the learning activities.

The mental model can be seen from students' ability to solve the cognitive problem consisting of C4-C6 problem. The Improved mental model results show the experiment class is better than the control class on each level of the question. This is because the experimental class students are accustomed to experimenting in real and virtuous Phet animations to find concepts. In addition the experimental class also facilitated physics learning website from the United States (Colorado: https://phet.colorado.edu/en/simulations/category/html) to support the learning activities, so that's where the mastery of the concept of students increases. The following is shown by the particle of three different substances in Figure 4.

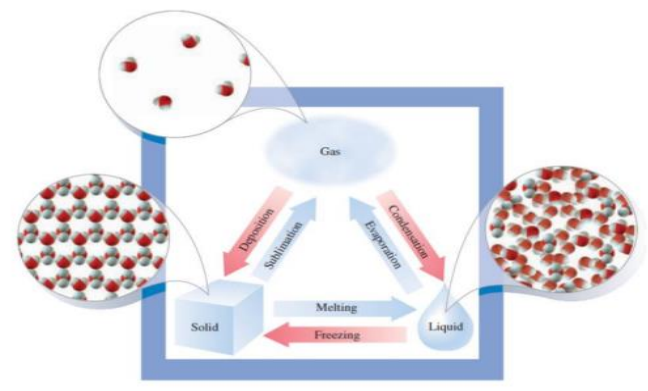

Figure 4. Scheme of substance change from solid, liquid to gas

In contrast to solids, liquids have less organized and less dense particles than the composition of particles in solids. This is what causes the particles to move freely to different places. However, the molecule particles cannot separate themselves from the group. This situation causes the volume of liquids to remain constant, although the shape always changes in place.

Problem based learning: Students' mental models on water conductivity concept (John Rafafy Batlolona) 
The results of the students' work in the experimental and control class proved a significant difference. This can be proved by the results of the experimental class work that answers better because the students have been taught with the correct concept both in the form of practice and simulation that stimulates better understanding of student concepts. By PBL, students also can search and find answers based on personal experiences of each student and can be shared with friends. Control groups rely more on individual ability to answer questions and are less supported by more modern learning so that students' knowledge to answer questions becomes doubtful and far from the scientific concepts of experts.

\section{CONCLUSION}

Based on the results of existing research, several conclusions are put forward. (1) Increased mastery of students' concepts studied with PBL is higher than students who learn with conventional learning. (2) Improved mental models of students with high early capability who learn by PBL is higher than students learning with conventional learning. (3) Improvement of low-skilled student mental models learning with PBL is higher than students learning with conventional learning. Thus the PBL model can be recommended in improving students' mental models on temperature and heat topics. The implication in this study is to improve the mental model of students as agents of change in science education.

\section{REFERENCES}

[1] G. Gardner, G. Jones, A. Taylor, J. Forrester, and L. Robertson, "Students' risk perceptions of nanotechnology applications: Implications for science education," Int. J. Sci. Educ., vol. 32, no. 14, pp. 1951-1969, 2010.

[2] M. Hegarty, M. Stieff, and B. L. Dixon, "Cognitive change in mental models with experience in the domain of organic chemistry," J. Cogn. Psychol., vol. 25, no. 2, pp. 220-228, 2013.

[3] T. Şenel Zor and O. Aslan, "The effect of activity-based nanoscience and nanotechnology education on pre-service science teachers' conceptual understanding," J. Nanoparticle Res., vol. 20, no. 3, 2018.

[4] C. Dankenbring and B. M. Capobianco, "Examining Elementary School Students' Mental Models of Sun-Earth Relationships as a Result of Engaging in Engineering Design," Int. Journal Sci. Math. Education, vol. 14, no. 5, pp. 825-845, 2016.

[5] R. D. Anderson, "Children's Ability to Formulate Mental Models to Explain Natural Phenomena," J. Res. Sci. Teach., vol. 3, no. 4, pp. 326-332, 1965.

[6] R. K. Coll and D. F. Treagust, "Learners' mental models of chemical bonding," Res. Sci. Educ., vol. 31, no. 3, pp. 357-382, 2001.

[7] R. K. Coll, B. France, and I. Taylor, "The role of models/and analogies in science education: Implications from research,” Int. J. Sci. Educ., vol. 27, no. 2, pp. 183-198, 2005.

[8] K. Adbo and K. S. Taber, "Learners' mental models of the particle nature of matter: A study of 16-year-old swedish science students," Int. J. Sci. Educ., vol. 31, no. 6, pp. 757-786, 2009.

[9] E. J. Park and G. Light, "Identifying Atomic Structure as a Threshold Concept: Student mental models and troublesomeness," Int. J. Sci. Educ., vol. 31, no. 2, pp. 233-258, 2009.

[10] N. Zarkadis, G. Papageorgiou, and D. Stamovlasis, "Studying the consistency between and within the student mental models for atomic structure," Chem. Educ. Res. Pract., vol. 18, no. 4, pp. 893-902, 2017.

[11] J. W. Lin and M. H. Chiu, "Exploring the characteristics and diverse sources of students' mental models of acids and bases," Int. J. Sci. Educ., vol. 29, no. 6, pp. 771-803, 2007.

[12] J. W. Lin and M. H. Chiu, "The mismatch between students' mental models of acids/bases and their sources and their teacher's anticipations thereof," Int. J. Sci. Educ., vol. 32, no. 12, pp. 1617-1646, 2010.

[13] D. F. Treagust, G. D. Chittleborough, and T. L. Mamiala, "Students' understanding of the descriptive and predictive nature of teaching models in organic chemistry," Res. Sci. Educ., vol. 34, no. 1, pp. 1-20, 2004.

[14] N. D. Körhasan and L. Wang, "Students' mental models of atomic spectra," Chem. Educ. Res. Pract., vol. 17, no. 4, pp. 743-755, 2016.

[15] J. J. Clement and M. S. Steinberg, "Step-Wise Evolution of Mental Models of Electric C ircuits : A "LearningAloud" Case Study," The Journal of the Learning Sciences, vol. 11,no. 4, pp. 389-452, 2009.

[16] M. Jabot and D. Henry, "Mental Models of Elementary and Middle School Students in Analyzing Simple Battery and Bulb Circuts," Sch. Sci. Math., vol. 107, no. 1, pp. 371-381, 2007.

[17] G. Nobes et al., "Children's understanding of the earth in a multicultural community: Mental models or fragments of knowledge?," Dev. Sci., vol. 6, no. 1, pp. 72-85, 2003.

[18] G. Panagiotaki, G. Nobes, and A. Potton, "Mental models and other misconceptions in children's understanding of the earth,” J. Exp. Child Psychol., vol. 104, no. 1, pp. 52-67, 2009.

[19] G. Beattie, et al., "An experimental investigation of some properties of individual iconic ...," Cognition, vol. 43, no. 2, pp. 1086-1109, 2006.

[20] K. Moon, et al., "Mental models for conservation research and practice," Conserv. Lett., pp. 1-11, 2019.

[21] K. LaMere, S. Mäntyniemi, J. Vanhatalo, and P. Haapasaari, "Making the most of mental models: Advancing the methodology for mental model elicitation and documentation with expert stakeholders," Environ. Model. Softw., vol. 124, pp. 104589, 2020.

Int. J. Eval. \& Res. Educ. Vol. 9, No. 2, June 2020: 269 - 277 
[22] B. Ahi, "A study to determine the mental models in preschool children's conceptualization of a desert environment," Int. Electron. J. Elem. Educ., vol. 8, no. 3, pp. 333-350, 2016.

[23] Ö. Özcan and S. Bezen, "Students' mental models about the relationship between force and velo city concepts," J. Balt. Sci. Educ., vol. 15, no. 5, pp. 630-641, 2016.

[24] M. C. Johnson-Glenberg, C. Megowan-Romanowicz, D. A. Birchfield, and C. Savio-Ramos, "Effects of embodied learning and digital platform on the retention of physics content: Centripetal force," Front. Psychol., vol. 7, no. NOV, pp. 1-22, 2016.

[25] S. J. Van Hook and T. L. Huziak-Clark, "Tip-to-tail: Developing a conceptual model of magnetism with kindergartners using inquiry-based instruction," J. Elem. Sci. Educ., vol. 19, no. 2, pp. 45-58, 2007.

[26] Ö. Özcan, "What are the students' mental models about the 'spin' and 'photon' concepts in modern physics?" Procedia - Soc. Behav. Sci., vol. 15, pp. 1372-1375, 2011.

[27] J. Aubert, D. Brito, H. Nataf, P. Cardin, and J. Masson, “Aubert et al_EPSL2001,” vol. 128, pp. 1-24, 2001.

[28] U. Besson, L. Borghi, A. De Ambrosis, and P. Mascheretti, "How to teach friction: Experiments and models," Am. J. Phys., vol. 75, no. 12, pp. 1106-1113, 2007.

[29] G. L. Chiou and O. R. Anderson, "A study of undergraduate physics students' understanding of heat conduction based on mental model theory and an ontology-process analysis," Sci. Educ., vol. 94, no. 5, pp. 825-854, 2010.

[30] G. L. Chiou, "Reappraising the relationships between physics students' mental models and predictions: An example of heat convection," Phys. Rev. Spec. Top. - Phys. Educ. Res., vol. 9, no. 1, pp. 1-15, 2013.

[31] P. S. Oh and S. J. Oh, "What teachers of science need to know about models: An overview," Int. J. Sci. Educ., vol. 33, no. 8, pp. 1109-1130, 2011.

[32] T. Corridoni, R. Mancinelli, M. A. Ricci, and F. Bruni, "Viscosity of aqueous solutions and local microscopic structure," J. Phys. Chem. B, vol. 115, no. 48, pp. 14008-14013, 2011.

[33] A. Derman, N. Koçak, and I. Eilks, "Insights into components of prospective science teachers' mental models and their preferred visual representations of atoms," Educ. Sci., vol. 9, no. 2, pp. 1-19, 2019.

[34] M. P. Clark, et al., "Water Resources Research," pp. 2498-2514, 2015.

[35] E. Lozano, J. Gracia, O. Corcho, R. A. Noble, and A. Gómez-Pérez, "Problem-based learning supported by semantic techniques," Interact. Learn. Environ., vol. 23, no. 1, pp. 37-54, 2015.

[36] C. E. Hmelo-silver, "Problem-Based Learning: What and How Do Students Learn?" JSTOR, vol. 16, no. 3, pp. 235-266, 2004.

[37] A. K. Burrow, "Teaching Introductory Ecology with Problem-Based Learning," Bull. Ecol. Soc. Am., vol. 99, no. 1, pp. 137-150, 2018.

[38] M. T. Borhan, "Problem Based Learning (PBL) in Teacher Education: a Review of the Effect of Pbl on Pre-Service Teachers' Knowledge and Skills," Eur. J. Educ. Sci., vol. 01, no. 01, pp. 76-87, 2014.

[39] S. H. Wells, P. J. Warelow, and K. L. Jackson, "Problem based learning (PBL): A conundrum," Contemp. Nurse, vol. 33, no. 2, pp. 191-201, 2009.

[40] A. J. Charlton-Perez, "Problem-Based Learning approaches in meteorology," J. Geosci. Educ., vol. 61, no. 1, pp. $12-19,2013$.

[41] W. Wartono, M. N. Hudha, and J. R. Batlolona, "How are the physics critical thinking skills of the students taught by using inquiry-discovery through empirical and theorethical overview?" Eurasia J. Math. Sci. Technol. Educ., vol. 14, no. 2, 2018.

[42] N. S. Ismail, J. Harun, M. A. Z. M. Zakaria, and S. M. Salleh, "The effect of Mobile problem-based learning application DicScience PBL on students' critical thinking,” Think. Ski. Creat., vol. 28, pp. 177-195, 2018.

[43] M. Sahin, "The impact of problem-based learning on engineering students' beliefs about physics and conceptual understanding of energy and momentum," Eur. J. Eng. Educ., vol. 35, no. 5, pp. 519-537, 2010. 